\title{
Andrzej Karpiński
}

\section{Przewartościowania w polityce gospodarczej wobec deindustrializacji}

\begin{abstract}
Streszczenie
Autor analizuje proces przewartościowania, do jakiego doszło w ostatnich latach w polityce gospodarczej w krajach najwyżej rozwiniętych oraz w Polsce. Dotyczy on stosunku do znaczenia przemysłu. W okresie dominacji nurtu neoliberalnego w polityce gospodarczej przemysł uznawano za sektor schyłkowy. Jego przedstawiciele byli przekonani, że ustąpi miejsca sektorowi usług jako wiodącemu, który bardziej napędza wzrost gospodarczy, ale w ciągu ostatnich 15 lat wiara w znaczenie usług załamała się i to w sposób niespodziewany. Wpłynęły na to technologiczne przeobrażenia w przemyśle, a także wybuch kryzysu globalnego na świecie w roku 2008.

Obecnie dyskurs w polityce ekonomicznej toczy się wokół zagadnienia potrzeby nowoczesnej reindustrializacji. Jest to również wyzwanie dla polskiej polityki gospodarczej. W Polsce doszło bowiem w ostatnich dwóch dekadach do nadmiernej deindustrializacji, co osłabiło szanse rozwojowe.
\end{abstract}

Słowa kluczowe: polityka gospodarcza, industrializacja, deindustrializacja, rozwój gospodarczy, globalizacja

\section{The new economics policy response to the de-industrialisation process}

\begin{abstract}
The author describes the policy change which took place within last years in the economic policy in the most developed countries as well as in Poland. That relates to the relevance of industrial sector in the world economy. During the prevalence of the neoliberal way of thinking in the economic policy it has been regarded as the one in decline. Its neoliberal advocates were convinced that this sector is going to be replaced by the service sector as a growth engine in the world economy. But with 15 years, quit unexpectedly, a belief in the relevance of it collapsed. That resulted from the technological progress in the industrial sector as well as the global economic crises which began in 2008 .
\end{abstract}


At present, the economic discourse revolves around the necessity of the modern reindustrialization. This is a challenge for the polish economic policy as well. In Poland we saw too much deindustrialization within last two decades, which weakened our prospects for development.

Keywords: economic policy, industrialisation, de-industrialisation, economic growth, globalisation

Jest rzeczą bezsporną, że ostatnie 15 lat przyniosło zasadniczą zmianę poglądów na temat przyszłości przemysłu na świecie. Jeszcze około 2000 r. istniało silne przekonanie, że przemysł i tradycyjne uprzemysłowienie jako droga rozwoju kraju odchodzą już do historii. Przemysł traktowano jako dział gospodarki, który jest już schyłkowy, który nieuchronnie musi ustąpić miejsca sektorowi usług jako bardziej dynamicznemu, mocniej dynamizującemu gospodarkę i silniej napędzającemu wzrost gospodarczy. Innymi słowy, rolę przemysłu przejąć miały sektory silniej oparte na nauce i informacji. Uznawano, że docelowym modelem gospodarki będzie tak zwana gospodarka oparta na wiedzy, która była przeciwstawiana modelowi gospodarki opartej na przemyśle. Warto podkreślić, że obecna zmiana stosunku do przemysłu nie może podważyć faktu, iż to gospodarka oparta na zasobach wiedzy jako podstawowym tworzywie ma wiodącą rolę w społeczeństwie i cywilizacji informacyjnej.

Oceniano także, że w przyszłości odsetek pracujących w przemyśle w odniesieniu do całego zatrudnienia w gospodarce będzie się zmniejszał nieprzerwanie aż do poziomu 2-3\% zasobów pracy. Byłby to zatem proces, którego odpowiednikiem był proces deagraryzacji, poprzedzający fazę cywilizacji przemysłowej.

Wydaje się, że w okresie transformacji w Polsce doszło do ugruntowania poglądu o schyłkowej roli przemysłu. W bardzo silnym stopniu wpłynęły na to m.in. dwie przyczyny. Pierwszą z nich było zwycięstwo doktryny neoliberalizmu w głównym nurcie ekonomii światowej (mainstream economics). Wprawdzie współczesny neoliberalizm miał swoje neo-klasyczne korzenie i nawiązywał wyraźnie do poglądów Adama Smitha i Davida Ricardo jeszcze z początku XIX w., jednakże na jego współczesny kształt wyraźny wpływ wywarli trzej ideolodzy, a mianowicie:

- Milton Friedman jako twórca nowoczesnego monetaryzmu,

- Manuel Castells jako przeciwnik determinizmu w nauce, co dotyczyło zwłaszcza nauk społecznych, a tym samym i ekonomii,

- Friedrich August von Hayek jako zwolennik nieograniczonej wolności człowieka, a tym samym wróg wszelkich form kolektywnej współpracy i współdziałania ludzi w realizacji celów społecznych. Zalążki tej teorii rozwijały się w nauce już wcześniej, ale na praktykę życia gospodarczego zaczęły wpływać dopiero na przełomie 
lat 70. i 80. ubiegłego stulecia, kiedy do władzy doszli M. Thatcher w Wielkiej Brytanii i R. Reagan w USA.

Skutkiem zwycięstwa powyższej doktryny była dominacja w gospodarce światowej sektora usług finansowych (banków i finansjery międzynarodowej) w skali uprzednio nigdy nieprzewidywanej. Stało się to kosztem ograniczenia funkcji państw narodowych, które w ciągu ostatnich 200 lat odgrywały wiodącą rolę w gospodarce. Upadek Związku Radzieckiego proces ten jeszcze przyśpieszył.

Ekspansja doktryny neoliberalnej miała wpływ również na politykę gospodarczą. Neoliberałowie krytykowali proces uprzemysłowienia na dwóch frontach. Zapowiedziano dematerializację produkcji, przesadnie ją interpretując, chociaż opierała się na realnych procesach, a mianowicie na silnej tendencji do wzrostu roli usług w przemyśle, które zwiększyły swój udział do 50\% ogółu czynności w przemyśle.

Drugą przyczyną ugruntowania poglądu o schyłkowej roli przemysłu była wzrastająca - począwszy od lat 60. ubiegłego stulecia - świadomość zagrożenia światowym kryzysem ekologicznym, spowodowanym ocieplaniem się klimatu, emisją zanieczyszczeń do atmosfery oraz rosnącą skalą strat z powodu ekstremalnych anomalii pogodowych. Źródeł tych zagrożeń dopatrywano się głównie w przemyśle, a zwłaszcza w przemyśle ciężkim, który w największym stopniu emituje zanieczyszczenia do atmosfery. Znalazło to wyraz w zaliczeniu go do tzw. „przemysłów dymiących" (smokestack-industries), mimo że w jeszcze większym stopniu źródłem tego zagrożenia stała się masowa motoryzacja. Uważano jednak, że w przemyśle można znaleźć łatwiej źródła redukcji zanieczyszczeń niż w procesie indywidualnej motoryzacji (podkreślali to zwłaszcza zwolennicy nieograniczonej wolności wyboru konsumenta).

Żmudnie budowana na tych przesłankach wizja schyłkowej roli przemysłu nagle i w sposób niespodziewany załamała się w ciągu ostatnich 15 lat. Wpłynęly na to dwie główne przyczyny:

1) fala odkryć naukowych z przełomu lat 80 . i 90. ,

2) kryzys globalny na świecie, który wybuchł w $2008 \mathrm{r}$.

Spójrzmy na pierwszą przyczynę. Na przełomie lat 80. i 90. XX w. doszło do fali odkryć naukowych, a wśród nich kluczowe było upowszechnienie Internetu. Zauważono, że umasowienie tych technologii w gospodarce i społeczeństwie wymaga ich adaptacji przez przemysł.

Druga przyczyna załamania poglądu o schyłkowej roli przemysłu związana była w znacznym stopniu $\mathrm{z}$ wybuchem kryzysu globalnego w $2008 \mathrm{r}$. Jest on nadal daleki od zakończenia, mimo że państwom udało się złagodzić jego objawy w ostatnich latach. Odwrotnie, nasilają się głosy, że jesteśmy dopiero w przededniu najtrudniejszej fazy tego kryzysu. T. Picketty w opublikowanej w 2013 r. i szeroko komentowanej 
pracy $^{1}$ ocenia, że obecny system ma charakter „samoniszczący” (self-destructive). Jego zdaniem ma dojść do narastania konfliktu między kapitałem a pracą, co musi nieuchronnie doprowadzić do upadku dzisiejszego systemu gospodarczego.

Obecny kryzys szczególnie silnie uderzył w sferę usług. Z reguły kryzysy zawsze prowadzą do zmniejszenia roli sektora usług, który jest bardziej wrażliwy i podatny na ich przejawy. Jest to zrozumiałe. Łatwiej jest bowiem zastąpić własną pracą usługi świadczone nam przez podmioty zewnętrzne niż produkcję, np. łatwiej zrezygnować $\mathrm{z}$ usług pralni niż samemu wyprodukować koszulę.

Kryzys ujawnił równocześnie - $\mathrm{z}$ większą niż dotychczas siłą - nieprawidłowości i wady w strukturze sektora usług. Ich przykładem może być nadmierna skala rozwoju tzw. „usług jałowych” (hollow services), jak np. reklamowe czy działalność parabanków. Nie dają one pozytywnych efektów makroekonomicznych poza przynoszeniem zysków ich świadczeniodawcom, uzyskiwanych nie zawsze w sposób zgodny z prawem i interesem ogólnospołecznym. Prowadzi to do powstania niekorzystnej struktury sektora usług, czego Polska jest jednym z najbardziej niepokojących przykładów.

Ponadto na zmianę poglądu na przyszłość przemysłu wpłynął również w istotny sposób fakt, że przyjmowane w prognozach i przewidywaniach na temat przyszłości przemysłu założenia okazały się co najmniej w trzech przypadkach zupełnie błędne. Co więcej, one całkowicie rozeszły się z rzeczywistym rozwojem sytuacji. Sprawa ta ma zasadnicze i strategiczne wręcz znaczenie, a więc wymaga omówienia.

\section{Błędna ocena roli Chin w przemyśle światowym}

Nurt neoliberalny dyktował w dyskursie ekonomicznym znaczenie wielu podstawowych pojęć, które są istotne w polityce gospodarczej. Objęło to również kwestię celów produkcji. W wyniku tego doszło do dominacji kwestii rentowności (zysku) wśród różnych celów działalności ekonomicznej człowieka. Neoliberałowie promowali rentowność nie tylko jako główne, ale niemal jako wyłączne kryterium stosowane dla oceny poziomu realizacji celów rozwoju przemysłu. Doprowadziło to do ekonomizacji życia gospodarczego w skali uprzednio niewyobrażalnej.

Głównym hasłem w obozie neoliberalnym stała się kwestia obniżki kosztów pracy. Oczywiście, na ten parametr decydujący wpływ ma wysokość płac. Postawiło to w uprzywilejowanej pozycji państwa o najniższych kosztach pracy. Państwa, które

1 T. Piketty, Capital In The Twenty-First Century, London 2014. Wydanie polskie: Wydawnictwo Krytyki Politycznej, Warszawa 2015. 
już osiągnęły wysoki poziom płac nie były w stanie sprostać wymogom konkurencji pod tym względem.

W uprzywilejowanej pozycji znalazły się Chiny, gdzie tamtejszy robotnik od stuleci był skłonny pracować za przysłowiową „miskę ryżu”. Zapoczątkowało to przenoszenie się produkcji pracochłonnej z krajów najwyżej rozwiniętych, o najwyższym poziomie płac, do krajów o najniższych kosztach pracy. Proces ten przybrał skalę światową i zyskał nazwę „delokalizacji”. Uznano, że ten proces będzie trwały.

Niektórzy wyciągnęli jednak z tego zbyt radykalne wnioski. Do tych osób, które poszły najdalej zaliczyć należy w pierwszym rzędzie $\mathrm{M}$. Thatcher. Doszła ona do wniosku, że w przyszłości Chiny staną się „fabryką przemysłową ludzkości”, a krajom wysokorozwiniętym pozostanie funkcja tworzenia rozwiązań naukowych i technicznych oraz rozwijanie produkcji o największych wymogach pod tym względem.

Była to $\mathrm{w}$ istocie nowa koncepcja międzynarodowego podziału pracy w skali globalnej. W jej ramach robotnik chiński miał pracować za „miskę ryżu” dla całej ludzkości, a inne kraje trzeciego świata miały dostarczać surowców i półfabrykatów o niskim stopniu przetworzenia surowców wyjściowych czy też odgrywać rolę podwykonawców dla państw najbogatszych. Była to w istocie koncepcja utrwalenia niekorzystnego podziału pracy dla krajów opóźnionych w rozwoju.

Na podstawie powyższych założeń działał rząd M. Thatcher i dlatego zdecydował się na wycofanie wszystkich rządowych zachęt dla rozwoju własnego przemysłu². W terminologii angielskiej w skrócie nazywane są one pro’s i obejmują środki promocyjne wszelkiego rodzaju. M. Thatcher liczyła równocześnie, że podobną drogą pójdą państwa Europy kontynentalnej, nie mówiąc już o USA, o poglądach skrajnie neoliberalnych.

Słabością tych poglądów okazały się jednak trzy fakty. Po pierwsze, robotnik chiński nie chciał pracować za "miskę ryżu”. Dlatego w miarę powstawania odpowiednich warunków w przemyśle chińskim zaczął się szybki wzrost płac. Na tej podstawie „The Economist" przewidywał, że jeszcze przed 2020 r. należy się liczyć z końcem zalewu na rynku światowym tanich towarów chińskich.

Po drugie, Chiny nie chciały zgodzić się na produkcję prymitywnych towarów niskiej jakości. Mało tego, zdobyte w wyniku takiej produkcji środki wykorzystano do budowy różnych sektorów własnego przemysłu o wysokiej technice. Chińczycy świadomie ściągali do siebie z innych krajów przemysł wytwarzający towary o wysokich cechach jakościowych i wymaganiach technologicznych. Dzisiaj mają w swoim eksporcie wyższy udział wyrobów o wysokiej technice niż ma średnio Unia Europejska (nie mówiąc już o Polsce, gdzie udział ten jest co najmniej 3-4-krotnie niższy niż w Chinach, a różnica wciąż rośnie na naszą niekorzyść).

2 No land of giants, „The Economist”, 26 listopada 2011, s. 26. 
Po trzecie, państwa Europy kontynentalnej nie redukowały na ogół tak radykalnie zachęt dla własnego przemysłu jak Wielka Brytania. Wynikiem tego był upadek przemysłu brytyjskiego w skali uprzednio nieprzewidywanej. W rezultacie Wielka Brytania stała się państwem o najgłębszej deindustrializacji w powojennej Europie, obok Polski, jeżeli pominąć byłą NRD. O skali upadku przemysłu brytyjskiego może świadczyć najgłębszy w Europie spadek zatrudnienia w przemyśle, z $8 \mathrm{mln}$ osób w szczytowym jego momencie do mniej niż 4 mln obecnie. Równocześnie na rynek brytyjski w miejsce przedsiębiorstw krajowych w dużej mierze weszły nie tylko zakłady prywatne należące do obywateli innych państw, ale również zakłady państwowe $\mathrm{z}$ innych krajów.

Skala deindustrializacji bliższa jest katastrofie przemysłowej niż normalnemu procesowi. Stąd trudno nam w Polsce wyobrazić sobie obecne nasilenie krytyki polityki $\mathrm{M}$. Thatcher w stosunku do przemysłu brytyjskiego, nawet na łamach prasy konserwatywnej. Ostatnio w „The Guardian” (nie jest to pismo konserwatywne) opublikowana została poważna krytyka prywatyzacji w przemyśle w Wielkiej Brytanii³

W sumie więc nie potwierdziły się oczekiwania, że Chiny staną się „fabryką przemysłową świata przyszłości", co ma poważne konsekwencje nie tylko poznawcze, ale i praktyczne. Może to być także dla nas ważnym ostrzeżeniem.

\section{Niedocenianie roli III rewolucji przemysłowej - robotyzacja}

Przez długie lata, jak wspomniałem wyżej, przewidywano, że czeka nas rewolucja technologiczna, ale nie chciano dopuścić myśli, iż będzie ona miała również istotny wpływ na sytuację w przemyśle. Wystarczy uświadomić sobie tylko dwa fakty. Jeżeli założyć, że w przyszłej cywilizacji informacyjnej co najmniej jedna trzecia ludności świata będzie musiała dysponować własnym laptopem, to trzeba będzie wyprodukować około 1,5-2 mld tych urządzeń. Żadne zakłady małe i średnie problemu tego nie rozwiążą.

Prognozy światowe są też zgodne co do tego, że stoimy w obliczu rewolucji technologicznej związanej z wprowadzeniem robotów na masową skalę, co może w perspektywie lat 30. bieżącego stulecia oznaczać przełom o głębi nie mniejszej

3 J. Meek pisze na łamach „The Guardian” z 22 sierpnia 2014 r.: „Prywatyzacji nie udało się przekształcić Wielką Brytanię w naród małych udziałowców. Zanim Thatcher doszła do władzy, prawie $40 \%$ akcji wielkich kompanii należało do osób prywatnych. W momencie kiedy umarła w 2013 r., spadł (udział ten - A.K.) poniżej 12\%”. Oznaczało to całkowite fiasko dotychczasowej polityki i zwycięstwo ponadnarodowych korporacji. 
niż upowszechnienie Internetu. Przełom ten nastąpi nie tylko w przemyśle, gdzie robotyzacja przebiega jak dotychczas z opóźnieniem w stosunku do uprzednich przewidywań, ale przede wszystkim w sferze usług ${ }^{4}$. Jeżeli założyć, że około $2030 \mathrm{r}$. liczba robotów, głównie usługowych, może wynieść od 15 do $20 \mathrm{mln}$ sztuk, to muszą być one produkowane właśnie w przemyśle.

Wreszcie z prognoz ludnościowych wynika, że w 2030 r. liczba ludności świata przekroczy 9 mld osób, a więc liczba konsumentów będzie większa o 1,8 mld niż obecnie. Trzeba będzie wyprodukować dobra materialne do dodatkowej konsumpcji, a zatem same usługi nie wystarczą. Ten sposób rozumowania można kontynuować. W rezultacie możemy być dziś prawie pewni, że III rewolucja przemysłowa będzie rewolucją:

- cyfrową, opartą na nowoczesnym sprzęcie teleinformatycznym,

- ekologiczną, a produkcja dóbr i usług dla ochrony środowiska i klimatu będzie głównym sektorem wzrostu w XXI w.,

- kosmiczną, oznaczającą przejście od eksploracji do eksploatacji kosmosu,

- opartą na wdrożeniu w masowej skali robotów w sferze usług i przemysłu,

- zagospodarowania zasobów surowcowych w rejonie Arktyki, gdzie znajdują się największe nowo odkryte zasoby tych surowców.

Nietrudno dostrzec, że wszystkie te pięć dziedzin wymagać będzie ekspansji przemysłu, który w realizacji każdego z tych zadań będzie odgrywał wyjątkowo ważną, a czasem nawet decydującą wręcz rolę. Nie potwierdziły się więc poglądy, że przejścia do nowej generacji zdobyczy nauki i nowoczesnych technologii będzie można dokonać bez nowej, drugiej z kolei, rewolucji przemysłowej.

\section{Nieodwracalność zmian w przemyśle nierozwojowym}

W latach 70. ubiegłego stulecia wykształciło się pojęcie „przemysłu nierozwojowego", sektorów kojarzonych z tradycyjnym przemysłem. One już w latach 1980-2000 przeżywały okres stagnacji bądź regresu w popycie na swoje wyroby na rynku światowym. Uznawano, że trudności na tym tle będą miały trwały charakter.

Do tej grupy zaliczono głównie przemysł wytwarzający tradycyjne dobra, w tym zwłaszcza związany z głównymi gałęziami przemysłu ciężkiego. Jego rozwój uległ bowiem wyraźnemu zahamowaniu w końcu XX w. i nastąpiło ograniczenie inwestycji. Główny wysiłek skierowano na racjonalizację zużycia wyrobów wytwarzanych w tych gałęziach przemysłu, a nie na ich dalszy rozwój. W grupie tej znalazło się m.in.

\footnotetext{
4 Zob.: The Rise of Robots, „The Economist”, 13 marca 2014, s. 35.
} 
hutnictwo żelaza, przemysł włókienniczy, przemysł nawozowy, taboru kolejowego i stoczniowy.

Przewidywania te opierały się równocześnie na przeświadczeniu, że w Chinach nie ukształtuje się taka struktura konsumpcji, jaka występuje w USA i Unii Europejskiej, co miało wynikać z odmienności tradycji obyczajowych i kulturowych. Całkowitym zaskoczeniem jest to, że w ciągu ostatnich 15 lat, wbrew oczekiwaniom, wystąpiła w Chinach bardzo silna tendencja naśladowania Zachodu w konsumpcji.

Największe zdziwienie wiąże się z dwoma procesami. Pierwszy, to przechodzenie Chińczyków od diety ryżowej do mięsnej, która jest kilkakrotnie bardziej kosztowna. Następstwem tego był m.in. wzrost zapotrzebowania na tradycyjne artykuły rolne.

Drugi proces, który stanowi jeszcze większe zaskoczenie, to silna tendencja do rozwoju motoryzacji indywidualnej, podczas gdy eksperci liczyli raczej, że w Chinach będzie dominował transport zbiorowy. Tymczasem według planów rządu chińskiego w ciągu najbliższych 10 lat zostanie wyprodukowanych w tym państwie około $500 \mathrm{mln}$ samochodów osobowych. Na tle liczby obecnie używanych na świecie aut, wynoszącej ok. 1,7 mld, oznaczałoby to wzrost o jedną trzecią.

Następstwem tego stało się znaczne zwiększenie, w skali uprzednio nieprzewidywanej, zapotrzebowania rynku światowego, zwłaszcza chińskiego, na tradycyjne wyroby uważane za nierozwojowe. Najlepszym tego przykładem może być światowa produkcja stali, która wzrosła z $847 \mathrm{mln}$ t do $1547 \mathrm{mln}$ t w 2012 r., podczas gdy jeszcze ok. 2000 r. przewidywano, że ona nie wzrośnie. Rezultatem tej nowej sytuacji stało się pewne ożywienie rozwoju produkcji w gałęziach przemysłu uważanych dotychczas za nierozwojowe. Towarzyszy mu w niektórych sektorach tendencja do „rewitalizacji” oraz wzrost cen niektórych surowców do wytwarzania tych tradycyjnych wyrobów.

Można więc z pełnym uzasadnieniem stwierdzić, że nie spełniły się dotychczasowe przewidywania dotyczące regresu lub trwałej stagnacji w gałęziach przemysłu nierozwojowego. Może to być zjawisko przejściowe, nie wiemy jak długo będzie ono trwało. Sytuacja ta może ulec zmianie dopiero w wypadku zahamowania obecnej dynamiki rozwoju Chin, co w dłuższym okresie wydaje się nieuchronne. Miałoby to jednak bardzo ujemne następstwa dla gospodarki światowej. Ocenia się bowiem, że spowolnienie rozwoju Chin może spowodować spadek średniego rocznego tempa wzrostu produktu krajowego brutto na świecie o 0,5 punktu procentowego rocznie.

Przedstawione wyżej fakty wskazują wyraźnie, że błędy w ocenie perspektyw przemysłu światowego oddziaływać będą silnie również na dalszy rozwój sytuacji w gospodarce. 


\section{Konsekwencje zmiany poglądów na rozwój przemysłu}

Trzeba zacząć od zmian klimatu wokół rozwoju przemysłu. Szczególnie charakterystyczna z tego punktu widzenia może być wypowiedź V. Cable’a, ministra biznesu w konserwatywnym rządzie D. Camerona w Wielkiej Brytanii. Sprowadza się ona do stwierdzenia konieczności znalezienia nowej równowagi i odejścia od obecnej formy rozwoju gospodarczego opartego głównie lub wyłącznie na usługach. Jego zdaniem, oznacza to konieczność odejścia od dominacji usług finansowych na rzecz wzmocnienia pozycji konkurencyjnej Wielkiej Brytanii w sektorach wytwarzania bardziej trwałych materiałów (more tangible stuff) ${ }^{5}$.

W ślad za tym zmieniły się również poglądy na procesy nazwane „deindustrializacją". W literaturze wyróżnia się dwie formy deindustrializacji. Jedna z nich uważana była za zjawisko naturalne po osiągnięciu najwyższej, najbardziej dojrzałej fazy procesu uprzemysłowienia. Druga to deindustrializacja przedwczesna, niemająca uzasadnienia w ogólnych prawidłowościach. Wprawdzie już poprzednio dostrzegano patologiczne cechy takiej deindustrializacji, jednak po 2008 r. jej krytyka nasiliła się, jak nigdy przedtem. D. Rodrik nazwał tę patologiczną formę deindustrializacji „Wczesną utratą przemysłu” (early loss of industry), a znany ekonomista indyjski - Subramanian - określił ją jako „przedwczesną nie-industrializację” (premature non-industrialisation $)^{6}$. Nigdy wcześniej nie poświęcono tyle uwagi ujemnym zjawiskom i następstwom przedwczesnej deindustrializacji, jak obecnie.

Pojawia się pytanie o wnioski dla Polski wynikające z powyższej debaty na temat roli przemysłu. Otóż kształtuje się u nas nowa opinia głosząca, że doszło do przedwczesnej deindustrializacji, co jest szczególnie szkodliwe i niebezpieczne dla krajów o niskim poziomie dochodów. Polska się do nich zalicza. Pod względem wysokości dochodów zajmujemy dopiero 25. miejsce wśród 28 państw Unii Europejskiej. Za nami są tylko Bułgaria i Rumunia. Jest to więc dla nas wniosek szczególnie aktualny.

Tygodnik „The Economist” pisze: „Utrata przemysłu na etapie niskich dochodów blokuje wkład, który przetwórstwo przemysłowe może wnieść do krajowych poziomów życia. A to nie jest już małym problemem: nie ma jasnej alternatywy strategii dla przekształcania krajów biednych w bogate"7.

Powyższy cytat wskazuje, że „The Economist” diametralnie zmienił dotychczasowe stanowisko w omawianej tu kwestii. Jeszcze niedawno usilnie lansował w niemal każdym

5 No land..., op.cit.

6 Special Report: The great wave, „The Economist”, 4 października 2014, s. 15.

7 Ibidem. 
swoim numerze tezę, że: „aby być bogatym, nie trzeba mieć zakładu przemysłowego na każdej ulicy". Dlatego rację miał P. Kuczyński, polski publicysta znany ze swoich wyważonych poglądów ekonomicznych, kiedy stwierdzał: „...uznano, że przemysł to przeszłość i trzeba stawiać na usługi. Teraz już wszyscy wiedzą, że trwałe miejsca pracy z dobrym wynagrodzeniem daje przemysł, a nie sieci handlowe".

\section{Przemysł i walka z kryzysem}

W takim klimacie pojawiła się silna tendencja do uznania przemysłu za główne i najbardziej skuteczne narzędzie walki z kryzysem. Stąd wynika niezwykła popularność w ostatnim okresie takich terminów jak: „ożywić przetwórstwo przemysłowe” (boosting manufacturing) czy „odbudować przetwórstwo przemysłowe” (reviving manufacturing) $)^{9}$.

Stąd była już prosta droga do podjęcia problemu „reindustrializacji”. Termin ten stał się synonimem dążenia do budowy nowego przemysłu w strukturze dostosowanej do technologii XXI w. W rezultacie w ciągu ostatnich pięciu lat hasło „nowoczesnej reindustrializacji” stało się jak najbardziej popularnym i najczęściej powtarzanym terminem w aktualnej publicystyce gospodarczej i wśród polityków.

Przedstawione wyżej zmiany poglądów nie mogły nie wpłynąć również na stanowisko instytucji Unii Europejskiej w tej sprawie. W oficjalnych dokumentach Unii stwierdzono fakt, że państwa UE o silniejszym przemyśle lepiej przeszły przez okres kryzysu (2008-2014) niż te, w których dominuje sektor usług, zwłaszcza finansowych.

Radykalną zmianę stosunku UE do przemysłu pokazuje uchwała Rady Europy, która uznała, że: „Reindustrializacja jest szansą dla Europy”. Ponadto, na jesieni 2012 r. Komisja Europejska przyjęła strategię reindustrializacji Unii, zakładającą zwiększenie udziału przemysłu w tworzeniu PKB w 2020 r. do 20 proc. $^{10}$. Nabiera to szczególnej wymowy wobec faktu, że jeszcze w 2003 r. ówczesny kanclerz Niemiec G. Schroeder oskarżał Unię i jej organy o negatywny stosunek do przemysłu, graniczący wręcz z obsesją czy uprzedzeniem (anti-industrial bias) $)^{11}$.

Rzeczywiście, jeśli Europa chce zachować aktywną rolę w gospodarce światowej w przyszłości, to musi uznać, że nie osiągnie tego poprzez same usługi (finansowe czy też obsługę biznesu lub ludności). Nie oznacza to, że rola pewnych usług nie będzie rosła, jak np. usługi dla starzejących się grup wiekowych.

\footnotetext{
8 Lepiej może już nie być, „Przegląd”, 18 sierpnia 2014, s. 20.

9 No land..., op.cit., s. 46.

10 „Przegląd”, 29 września 2014, s. 20.

${ }^{11}$ A golden age?, „The Economist”, 26 lutego 2014, s. 63.
} 
Obecnie niewątpliwie reindustrializacja jest jedną z najbardziej nowoczesnych form procesu uprzemysłowienia.

\section{Wnioski dla świata, Europy, Polski}

Istnieje duże prawdopodobieństwo, że w ciągu 10 lat należy się liczyć z ukształtowaniem się nowego międzynarodowego podziału pracy. W jego ramach bardziej aktywną rolę będą odgrywać państwa BRIC (Brazylia, Rosja, Indie, Chiny).

Dla USA oznaczać to będzie konieczność utrzymania, a nawet jeszcze wzmocnienia, ich decydującej roli w rozwoju przemysłu nowej techniki i najwyższych technologii. Oznacza to konieczność obrony głównych dotychczasowych celów strategii, którą zarysował Z. Brzeziński. Sprowadza się ona do tezy, że najważniejszym celem strategicznym dla USA musi być utrzymanie ich wiodącej roli i wyprzedzenie innych krajów w rozwoju przemysłu najnowszych technologii.

Unia Europejska potrzebować będzie znacznie większych zmian, a zwłaszcza określenia jej nowej specjalizacji w gospodarce i przemyśle. Sektor usług, nawet najbardziej perspektywicznych, związanych z obsługą ludności w wieku dożywania, już w tym celu nie wystarczy. Wydaje się, że zalążki takiej nowej specjalizacji w Europie mogą się pojawić w przemyśle ekologicznym, gdzie Europa jest znacznie bardziej zaawansowana niż USA czy Japonia, a tym bardziej Chiny.

Drugą potencjalną specjalizacją dla Europy może być rozwój dziedzin dostarczających sektorowi publicznemu wytwarzanych w przemyśle dóbr i usług, używanych w tym sektorze (na pewno dotyczy to sprzętu dla edukacji, ochrony zdrowia i ochrony środowiska). Europa ma bowiem wciąż jeszcze silniejszą pozycję w rozwoju tego sektora niż USA, jak również więcej doświadczeń w skutecznym rozwiązywaniu konfliktów między kapitałem a pracą.

Jeszcze bardziej radykalne wnioski wynikają z przedstawionej wyżej sytuacji dla Polski. Państwo powinno mieć strategię działań, która zapewni wyjście z półkolonialnego charakteru powiązań z rynkiem światowym ${ }^{12}$. Dotychczasowa linia działania nie wystarczy. Potrzebne są jej głębokie zmiany, które można ująć w czterech założeniach:

- nie wystarczy nam do zapewnienia rozwoju choćby najlepiej rozwinięty sektor usług, nawet o zmodernizowanej strukturze,

- nie wystarczy sam rozwój małych i średnich przedsiębiorstw, a tym bardziej pełnienie roli tylko „podwykonawcy” dla światowych koncernów,

12 Zob. A. Karpiński, Kontynuować czy zmienić?, Wydawnictwo Elipsa, Warszawa 2014, s. 68-74. 
- konieczna będzie odbudowa zakładów dużych z uwagi na nadmierną dekoncentrację przemysłu w Polsce, jaka nastąpiła w minionym okresie transformacji systemowej, co może w warunkach globalizacji zapewnić większą zdolność do konkurencji na rynkach zagranicznych, zwłaszcza tych, które opierają swoją konkurencyjność nie tylko na niskich płacach, ale i zdolności do innowacji,

- nie wystarczy nam sam dotychczasowy sukces w powrocie do kapitalizmu jako formy ustrojowej, aby sprostać wyzwaniom również w sferze realnej, konieczna jest nowoczesna reindustrializacja.

Uchwyćmy na koniec nasz podstawowy problem w polityce gospodarczej, przed którym obecnie stoimy. Otóż można go sformułować następująco - musimy zahamować naszą przedwczesną i patologiczną deindustrializację i wejść na drogę nowoczesnej reindustrializacji.

W innym wypadku nasza droga rozwoju w przemyśle rozejdzie się całkowicie z trendami globalnymi i strategią Unii Europejskiej. Gdy nie podołamy temu - zmniejszą się w zasadniczy sposób nasze szanse na sukces i zdolność do sprostania wyzwaniom przyszłości w XXI wieku.

\section{Bibliografia}

A golden age?, „The Economist”, 26 lutego 2014.

Karpiński A., Kontynuować czy zmienić?, Wydawnictwo Elipsa, Warszawa 2014.

Lepiej może już nie być, „Przegląd”, 18 sierpnia 2014.

Meek J., „The Guardian”, 22 sierpnia 2014.

No land of giants, „The Economist”, 26 listopada 2011.

Piketty T., Capital In The Twenty-First Century, London 2014.

Special Report: The great wave, „The Economist”, 4 października 2014.

The Rise of Robots, „The Economist”, 13 marca 2014. 